\title{
Simulasi Rancangan Pemetaan Sekolah dengan Metode Algoritma Machine Learning Menggunakan Software RapidMiner
}

\author{
Aisyah Sabrina Aprilia $^{1}$, Budi Aribowo ${ }^{1}$, Ahmad Chirzun $^{1}$ \\ ${ }^{1}$ Program studi Teknik Industri, Fakultas Sains dan Teknologi, Universitas Al Azhar Indonesia, Komplek \\ Masjid Agung Al Azhar, Jalan Sisingamangaraja, Kebayoran Baru, Jakarta Selatan, 12110
}

Penulis untuk Korespondensi/E-mail: aisyahsabrinaaprilia@gmail.com

\begin{abstract}
The growth in the number of educational institutions creates competition which encourages each educational institution to have a special strategy to deal with it. The challenge that must also be faced in the world of education is the uneven quality of education in various regions. One way to face the challenge of equal distribution of school quality is to create programs that suit the needs of each school. In this study, solving the problem of mapping schools owned by the XYZ educational foundation was carried out. The results of this study obtained a design of a school mapping indicator instrument to assess the quality of each school. Then obtained a simulation of school mapping design from the results of unsupervised learning with the K-Means and K-Medoids Clustering methods, as well as a simulation of predicting school mapping patterns from the results of supervised learning with the Decision Tree C4.5 method. The results of K-Medoids were selected for the proposed school mapping with a Davies Bouldin index value of 0.112. The model cluster owned by K-Medoids, namely Excellent School, has 44 schools; at Good School, there are 36 schools; and in the Improvement School, there are 20 schools. Meanwhile, the prediction pattern with Decision Tree C4.5 obtained rules with the dominant indicator attributes (IND) 1, 2, 3, and 4. Also, the prediction simulation results using the 80:20 ratio decision tree model show the new testing data with the assumption that the 101st school goes to cluster_1 with an accuracy rate of $95 \%$.
\end{abstract}

Abstrak - Pertumbuhan jumlah lembaga pendidikan menimbulkan persaingan yang mendorong tiap lembaga pendidikan harus memiliki strategi khusus untuk menghadapinya. Tantangan yang juga harus dihadapi dalam dunia pendidikan adalah kualitas pendidikan yang tidak merata di berbagai daerah. Salah satu cara untuk menghadapi tantangan pemerataan kualitas sekolah adalah dengan membuat program yang sesuai dengan kebutuhan masing-masing sekolah. Pada penelitian ini, dilakukan pemecahan masalah pemetaan sekolah yang dimiliki yayasan pendidikan XYZ. Hasil dari penelitian ini didapatkan suatu rancangan instrumen indikator pemetaan sekolah untuk melakukan penilaian terhadap kualitas masing-masing sekolah. Kemudian didapatkan simulasi rancangan pemetaan sekolah dari hasil unsupervised learning dengan metode K-Means dan K-Medoids Clustering, serta simulasi prediksi pola pemetaan sekolah dari hasil supervised learning dengan metode Decision Tree C4.5. Hasil K-Medoids terpilih untuk usulan pemetaan sekolah dengan nilai davies bouldin index 0.112 . Cluster model yang dimiliki K-Medoids, yaitu Excellent School terdapat 44 sekolah; pada Good School terdapat 36 sekolah; dan pada Improvement School terdapat 20 sekolah. Sedangkan, pola prediksi dengan Decision Tree C4.5 didapatkan rules dengan atribut indikator (IND) 1, 2, 3, dan 4 yang mendominasi. Serta, hasil simulasi prediksi dengan menggunakan model decision tree rasio 80:20 didapatkan bahwa data testing baru dengan asumsi sekolah ke-101 masuk ke cluster_1 dengan tingkat akurasi sebesar $95 \%$.

Keywords - decision tree, K-means, K-medoids, school mapping indicator instrument. 


\section{PENDAHULUAN}

$\mathrm{P}$ endidikan menjadi hal yang penting untuk diperhatikan oleh negara demi membangun kualitas sumber daya manusianya. Dunia pendidikan harus terus berkembang untuk melakukan perbaikan yang berkelanjutan. Khususnya di Indonesia, perkembangan pendidikan terus dilakukan oleh pemerintah dengan berbagai cara guna mencerdaskan bangsanya. Selain itu, pendidikan juga menjadi salah satu rencana strategis pemerintah dalam rangka menghadapi MEA (Masyarakat Ekonomi ASEAN), sehingga Indonesia dapat bersaing dengan negara - negara lainnya.

Namun di tengah - tengah usaha perkembangan pendidikan tersebut, terdapat permasalahan yang masih dialami dunia pendidikan Indonesia. Masalah pemerataan dan akses pendidikan masih sulit dilaksanakan di Indonesia. Kondisi geografis menjadi salah satu faktor sulitnya pemecahan masalah tersebut, apalagi dengan kondisi geografis Indonesia yang merupakan negara kepulauan [1]. Hal tersebut menjadi tantangan utama bagi para pelaku dunia pendidikan untuk terus melakukan perkembangan demi kemajuan pendidikan Indonesia. Pemerataan kualitas pendidikan di setiap daerah merupakan langkah yang dapat dilakukan untuk peningkatan kualitas pendidikan di seluruh Indonesia [2]. Bukan hal yang buruk maupun sulit untuk dilakukan, tetapi hanya saja sistem pendidikan Indonesia belum dilaksanakan secara optimal [3].

Lembaga pendidikan merupakan suatu lembaga yang menyelenggarakan pendidikan dengan berusaha mencari langkah tepat untuk meningkatkan mutu pendidikan di sekolah dalam rangka memenuhi kebutuhan para siswa [4]. Banyaknya lembaga pendidikan yang hadir di Indonesia akan turut meramaikan dunia pendidikan serta menuntut setiap lembaga pendidikan memiliki strategi untuk menghadapi persaingan. Persaingan tersebut bersifat positif dalam mendorong kemajuan tiap lembaga pendidikan melakukan peningkatan kualitas pendidikan yang diselenggarakannya.

Penilaian sekolah dengan indikator tertentu dapat menganalisis kondisi mutu sekolah dalam suatu waktu. Menurut penelitian yang dilakukan Novita (2017), indikator penilaian sekolah dikatakan bermutu dari dinas pendidikan adalah memenuhi 8 SNP (Standar Nasional Pendidikan). Sedangkan, indikator mutu sekolah menurut orang tua siswa, yaitu akreditasi sekolah; kompetensi guru; lulusan siswa yang diterima sekolah/perguruan tinggi unggul; prestasi siswa baik bidang akademik dan non akademik; hasil Ujian Nasional (UN); dan karakter siswa. Dari hasil penilaian sekolah tersebut dapat dijadikan sebagai dasar pemetaan mutu sekolah.

Yayasan pendidikan XYZ merupakan salah satu lembaga pendidikan Islam milik swasta di Indonesia yang melaksanakan kegiatan pendidikan formal, terdiri dari taman kanak - kanak, sekolah dasar, sekolah menengah pertama, sekolah menengah atas, hingga universitas. Dalam menghadapi persaingan dengan lembaga pendidikan lainnya serta mengikuti perkembangan zaman, sekolah perlu terus tumbuh dan berkembang. Salah satu rencana strategis yang dirancang oleh yayasan adalah melakukan program pemetaan sekolah-sekolah yang dimilikinya guna menganalisis kondisi mutu sekolah serta memetakan sekolah ke dalam tiga tingkatan, yaitu Excellent School; Good School; dan Improvement School. Tingkatan Excellent School akan berisi sekolah yang memiliki tingkatan kualitas paling baik. Tingkatan Good School akan berisi sekolah yang memiliki tingkatan kualitas yang cukup baik. Sedangkan, tingkatan Improvement School akan berisi sekolah yang memiliki tingkatan kualitas yang masih kurang baik. Hasil pemetaan tersebut dapat dijadikan yayasan sebagai dasar untuk evaluasi, sehingga dapat dirancang program yang sesuai masingmasing kebutuhan sekolah.

Berdasarkan permasalahan tersebut, dibutuhkan rancangan pemetaan untuk sekolah yang dimiliki yayasan pendidikan XYZ, sehingga dapat diketahui pengelompokkan kualitas tiap sekolah yang dimilikinya. Pemetaan didasarkan dengan sejumlah indikator tertentu untuk penilaiannya. Dalam melakukan pemetaan dapat menggunakan peranan data mining berbasis metode algoritma machine learning. Clustering merupakan bagian dari unsupervised learning yang dapat dilakukan dengan metode K-Means dan K-Medoids. Dengan clustering tersebut, sekolah-sekolah akan memiliki karakteristik yang sama akan berkumpul pada cluster yang sama, sehingga dapat membentuk pemetaan sekolah. Selanjutnya, hasil clustering akan dijadikan sebagai input data pada metode Decision Tree C4.5 sebagai supervised learning yang melakukan klasifikasi. Dengan klasifikasi tersebut, akan didapatkan pola pemetaan sekolah untuk memprediksi sekolah masuk ke dalam suatu cluster tertentu. 


\section{METODE}

Desain, objek, dan waktu penelitian

Penelitian ini dilakukan pada Yayasan Pendidikan XYZ untuk memetakan serta melakukan simulasi prediksi sekolah pada jenjang SMA (Sekolah Menengah Atas). Waktu penelitian dilakukan pada Maret sampai Juli 2021.

\section{Jenis pengumpulan data}

Pengumpulan data dilakukan dengan menggunakan data primer dan generate random number. Data primer yang didapatkan dari hasil kuesioner dengan narasumber terkait, dalam hal ini terdapat tim pemetaan sekolah dari yayasan tersebut. Sedangkan, generate random number dilakukan menggunakan Microsoft Excel untuk asumsi 100 data sekolah dengan 9 indikator penilaian menggunakan. Generate random number dilakukan karena dalam batasan waktu penelitian belum didapatkan data primer dari yayasan tersebut, sehingga digunakan alternatif penggunaan data random number. Dari proses pengumpulan data, dihasilkan profil yayasan dan data sekolah milik yayasan pendidikan XYZ.

\section{Tahapan pengolahan dan analisis data}

Pada tahapan pengolahan data, dimulai dari perancangan indikator pemetaan sekolah. Dalam melakukan perancangan, dilakukan FGD (Focus Group Discussion) hingga didapatkan validasi rancangan instrumen pemetaan sekolah dari narasumber terkait. Dari sejumlah indikator yang terdapat pada rancangan instrumen pemetaan dilakukan reduksi dengan metode Value Engineering. Reduksi dilakukan karena adanya keterbatasan waktu pengumpulan data maupun adanya data yang belum tersedia (belum didokumentasikan). Hasil reduksi indikator kemudian dilakukan pembobotan nilai dengan AHP (Analytical Hierarchy Process) untuk pemeringkatan indikator. Himpunan data selanjutnya dikalikan dengan bobot dan dilakukan normalisasi data.

Setelah itu, dilakukan pengklasteran dengan metode K-Means dan K-Medoids Clustering, serta membandingkan hasil clustering dari kedua metode tersebut dengan metode Davies-Bouldin Index. Kemudian dilanjutkan pengklasifikasian dengan metode Decision Tree C4.5 untuk menemukan pola prediksi pemetaan sekolah dari hasil data training yang dihasilkan dari clustering. Perhitungan hasil akurasi pola rules hasil decision tree dilakukan dengan Confusion Matrix. Langkah terakhir, dilakukan simulasi pola decision tree untuk memprediksi label cluster untuk data testing suatu sekolah

\section{HASIL DAN PEMBAHASAN}

\section{Pengumpulan data}

Dilakukan generate random number untuk asumsi data penilaian 100 sekolah berdasarkan 9 indikator yang ditetapkan dengan rubrik penilaian level 1 sampai 4. Himpunan data tersebut akan dijadikan sebagai input dalam pengolahan data penelitian ini. "IND 1" merupakan nilai dari indikator tingkat pemenuhan daya tampung; "IND 2" merupakan nilai dari tertib LPJ keuangan yang outstanding; "IND 3" merupakan nilai dari persentase murid diterima PTN; "IND 4" merupakan prestasi akademik lembaga Kemendikbud/resmi; "IND 5" merupakan akreditasi sekolah; "IND 6" merupakan rata-rata penilaian DP4 guru; "IND 7" merupakan prestasi non-akademik lembaga Kemendikbud/resmi; "IND 8" merupakan persentase pemenuhan sarana dan prasarana; dan "IND 9" merupakan rata-rata penilaian DP4 tenaga kependidikan. Berikut pada Tabel 1 merupakan himpunan data sekolah hasil generate random number.

Tabel 1. Himpunan Data

\begin{tabular}{|c|c|c|c|c|c|c|c|c|c|}
\hline Sekolah & IND 1 & IND 2 & IND 3 & IND 4 & IND 5 & IND 6 & IND 7 & IND 8 & IND 9 \\
\hline 1 & 1 & 3 & 3 & 2 & 4 & 2 & 3 & 3 & 4 \\
\hline 2 & 4 & 3 & 3 & 4 & 2 & 4 & 4 & 4 & 4 \\
\hline 3 & 3 & 4 & 2 & 1 & 4 & 1 & 2 & 1 & 1 \\
\hline 4 & 2 & 2 & 3 & 3 & 3 & 3 & 3 & 1 & 3 \\
\hline 5 & 2 & 2 & 1 & 2 & 1 & 3 & 2 & 2 & 2 \\
\hline 6 & 3 & 1 & 1 & 4 & 2 & 3 & 4 & 1 & 3 \\
\hline 7 & 3 & 1 & 4 & 4 & 4 & 4 & 4 & 3 & 4 \\
\hline 8 & 1 & 3 & 2 & 4 & 2 & 2 & 1 & 4 & 4 \\
\hline 9 & 4 & 4 & 3 & 2 & 1 & 4 & 1 & 4 & 2 \\
\hline 10 & 3 & 2 & 3 & 3 & 4 & 2 & 4 & 3 & 3 \\
\hline$\ldots$ & $\ldots$ & $\ldots$ & $\ldots$ & $\ldots$ & $\ldots$ & $\ldots$ & $\ldots$ & $\ldots$ & $\ldots$ \\
\hline 100 & 2 & 4 & 2 & 1 & 2 & 3 & 2 & 3 & 2 \\
\hline
\end{tabular}

\section{Pengolahan data}

\section{Rancangan Instrumen Indikator Pemetaan Sekolah}

Perancangan instrumen indicator pemetaan dilakukan untuk penilaian kualitas masing-masing sekolah. Instrumen tersebut merupakan alat penilaian yang terdiri dari indikator dan rubrik penilaian, terdapat empat bagian penilaian sekolah yang terdiri dari, "Sekolah Ideal"; "Sekolah Sehat"; "Sekolah Mutu"; dan "Sekolah Juara". Setiap bagian memiliki indikator utama yang berisikan sejumlah sub-indikator yang akan dinilai berdasarkan 4 level rubrik. Penialain sekolah dikatakan "Sekolah Ideal" dilakukan dari indikator murid, SDM (Sumber Daya Manusia) guru, tenaga kependidikan, dan keuangan. 
Indikator utama dalam penilaian "Sekolah Sehat" adalah fasilitas. Indikator utama dalam penilaian "Sekolah Mutu" adalah mutu. Sedangkan indikator utama dalam penilaian "Sekolah Juara" adalah prestasi murid, prestasi guru, dan prestasi sekolah.

Perancangan instrumen telah melalui beberapa kali tahapan revisi dari pendapat sekretariat yayasan, pejabat eselon, pengawas sekolah, sampai dengan para kepala sekolah. Setelah melalui tahapan revisi dilakukanlah validasi oleh narasumber terkait. Rancangan instrumen indikator pemetaan sekolah yang dihasilkan terdiri dari 34 sub-indikator.

\section{Reduksi Indikator dengan Value Engineering}

Rancangan instrumen indikator pemetaan sekolah direduksi dengan metode Value Engineering. Dengan adanya reduksi tersebut maka akan terpilih sub-indikator prioritas yang akan digunakan dalam pengolahan data selanjutnya. Pada penelitian ini, digunakan lima tahapan dalam metode Value Engineering, yaitu tahapan informasi, kreatif, analisa, pengembangan, dan penyajian [6].

Tahap informasi dilakukan dengan kegiatan studi literatur dan FGD (Focus Group Discussion). Tahap kreatif dilakukan dengan kegiatan perancangan instrumen pemetaan sekolah. Tahap analisa dilakukan dengan melakukan penilaian terhadap sub-indikator pada instrumen pemetaan sekolah melalui kuesioner yang diisi oleh narasumber terkait, serta dilakukan pengolahan terhadap penilaian tersebut sehingga diperoleh matrik hasil penilaian indikator. Tahap pengembangan dilakukan dengan membandingkan hasil penilaian subindikator, kemudian dilakukan pemilihan subindikator dengan nilai tertinggi, serta dilakukan pertimbangan-pertimbangan tertentu melalui validasi pakar. Sedangkan tahap penyajian, dilakukan penyajian terhadap hasil sub-indikator yang terpilih.

Kuesioner yang disebarkan berbentuk penilaian tingkat kepentingan tiap sub-indikator pada instrumen pemetaan sekolah. Penilaian tingkat kepentingan tersebut dilakukan dengan skala semantik dari interval 1 (satu) sampai 7 (tujuh). Semakin sangat penting penilaian terhadap subindikator, maka bobot semakin besar yang mengarah ke kanan atau skala 7 (tujuh). Sebaliknya, semakin sangat tidak penting penilaian terhadap subindikator, maka bobot semakin kecil yang mengarah ke kiri atau skala 1 (satu).

Pemilihan indikator prioritas dilakukan berdasarkan nilai rata-rata skor yang tertinggi dari penilaian tingkat kepentingan oleh masing-masing pakar. Pakar yang melakukan penilaian kuesioner terdiri dari Pakar 1 yang merupakan Kepala Seksi Perencanaan dan Pengembangan Yayasan serta merupakan mantan Kepala SMA (Sekolah Menengah Atas); Pakar 2 yang merupakan Kepala Bidang Pengembangan Sumber Daya Manusia serta merupakan mantan Kepala SMA (Sekolah Menengah Atas); dan Pakar 3 yang merupakan salah satu anggota Bidang Pendidikan dan Pengembangan. Setelah dilakukan validasi pakar, didapatkan sembilan sub-indikator yang menjadi indikator prioritas, hasil tersebut telah mewakili masing-masing indikator utama. Berikut pada Tabel 2 merupakan rekapitulasi hasil indikator prioritas yang terpilih.

Tabel 2. Rekapitulasi Hasil Reduksi Value Engineering

\begin{tabular}{|c|c|c|c|c|}
\hline \multirow{2}{*}{ Indikator Prioritas dalam Pemetaan Sekolah } & \multicolumn{4}{|c|}{ Rubrik } \\
\hline & 1 & 2 & 3 & 4 \\
\hline Tingkat pemenuhan daya tampung sekolah & $<79 \%$ & $80-89 \%$ & $90-99 \%$ & $100 \%$ \\
\hline $\begin{array}{l}\text { Persentase jumlah murid yang diterima PTN } \\
\text { (Perguruan Tinggi Negeri) }\end{array}$ & $<10 \%$ & $10-29 \%$ & $30-49 \%$ & $>=50 \%$ \\
\hline Rata-rata penilaian DP4 guru & $0-49$ & $50-64$ & $65-79$ & $80-100$ \\
\hline Rata-rata penilaian DP4 tenaga kependidikan & $0-49$ & $50-64$ & $65-79$ & $80-100$ \\
\hline $\begin{array}{l}\text { Tertib Laporan pertanggungjawaban keuangan per } \\
\text { tahun (yang belum dilaporkan-Outstanding ) }\end{array}$ & $>3 \%$ & $2,1-3 \%$ & $1,1-2 \%$ & $0-1 \%$ \\
\hline $\begin{array}{l}\text { Persentase pemenuhan standar sarana dan prasarana } \\
\text { sekolah }\end{array}$ & $0-25 \%$ & $26-50 \%$ & $51-75 \%$ & $76-100 \%$ \\
\hline Akreditasi sekolah & $\begin{array}{c}\text { Belum } \\
\text { Terakreditasi }\end{array}$ & C (Cukup) & B (Baik) & A (Unggul) \\
\hline $\begin{array}{l}\text { Prestasi bidang akademik lembaga penyelenggara } \\
\text { Kemendikbud/Resmi }\end{array}$ & Juara Harapan & Perunggu/Juara 3 & Perak/Juara 2 & Emas/Juara 1 \\
\hline $\begin{array}{l}\text { Prestasi bidang non-akademik lembaga } \\
\text { penyelenggara Kemendikbud/Resmi }\end{array}$ & Juara Harapan & Perunggu/Juara 3 & Perak/Juara 2 & Emas/Juara 1 \\
\hline
\end{tabular}




\section{Pembobotan Indikator Prioritas dengan AHP (Analytical Hierarchy Process)}

Pembobotan indikator prioritas dilakukan dengan metode AHP menggunakan bantuan Software Super Decisions. Pembobotan didasarkan pada pengaruh dari masing-masing indikator prioritas terhadap penilaian pemetaan sekolah. Dalam pembobotan dengan metode AHP, dirancang struktur hirarki untuk mendefinisikan tujuan, kriteria, dan alternatif yang digunakan [7]. Berikut merupakan struktur hirarki dalam melakukan perhitungan dengan metode AHP.

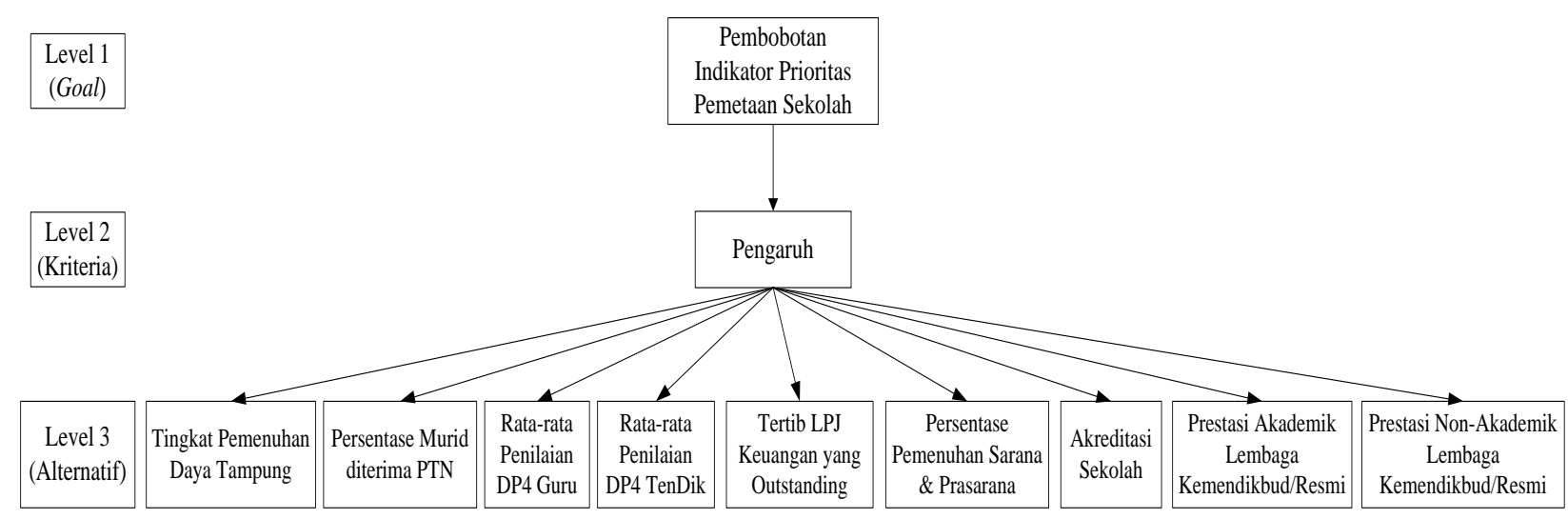

Gambar 1. Struktur Hirarki

Penilaian matriks perbandingan berpasangan dilakukan oleh 2 pakar, yaitu Pakar 1 dan Pakar 2 yang sama pada metode Value Engineering. Sedangkan Pakar 3 tidak dapat melakukan pengisian kuesioner AHP ini dikarenakan keterbatasan waktu yang dimiliki pakar. Hasil penilaian masing-masing pakar telah konsisten dengan nilai inconsistency sebesar 0,077 untuk Pakar 1 dan 0,067 untuk Pakar 2. Selanjutnya penggabungan hasil penilaian kedua pakar dilakukan dengan perhitungan geometric mean.

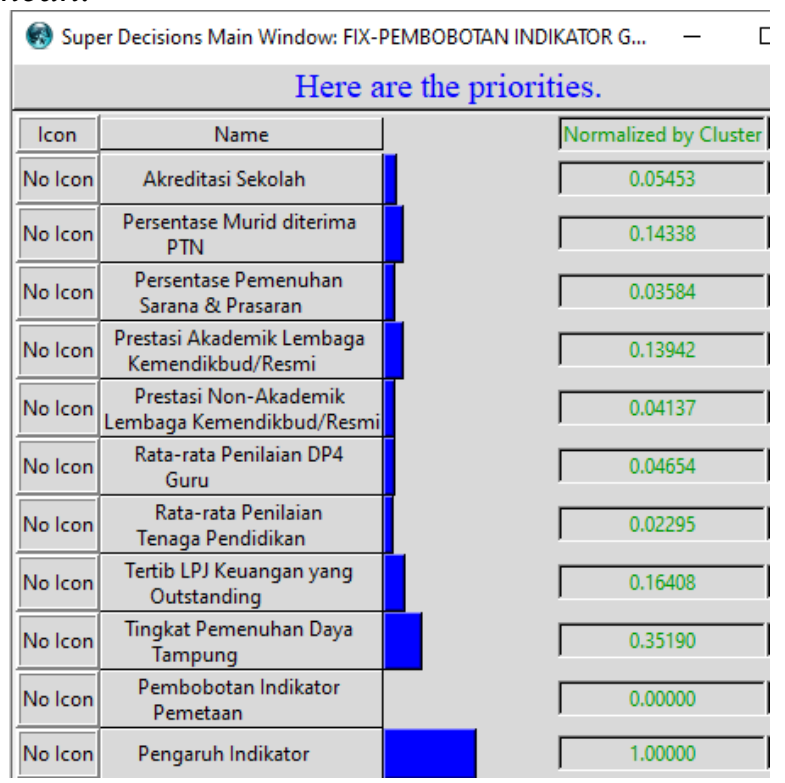

Gambar 2. Hasil Nilai Normalisasi

Gambar 2 di atas menunjukkan hasil akhir metode AHP dengan software Super Decisions. Hasil tersebut menunjukkan bobot normalisasi dari tiap elemen indikator prioritas. Nilai inconsistency yang didapatkan dari software setelah penggabungan penilaian Pakar 1 dan Pakar 2 adalah 0.038 sehingga dapat dikatakan konsisten. Hasil pembobotan tiap indikator prioritas dari perhitungan metode AHP ini selanjutnya dikalikan dengan himpunan data yang telah didapatkan dari hasil pengumpulan data. Berikut pada Tabel 3 merupakan hasil himpunan data yang telah dikalikan dengan hasil bobot perhitungan AHP.

Tabel 3. Himpunan Data Hasil Pembobotan

\begin{tabular}{|c|c|c|c|c|c|c|c|c|c|}
\hline Sekolah & IND 1 & IND 2 & IND 3 & IND 4 & IND 5 & IND 6 & IND 7 & IND 8 & IND 9 \\
\hline 1 & 0.352 & 0.492 & 0.430 & 0.279 & 0.218 & 0.093 & 0.124 & 0.108 & 0.092 \\
\hline 2 & 1.408 & 0.492 & 0.430 & 0.558 & 0.109 & 0.186 & 0.165 & 0.143 & 0.092 \\
\hline 3 & 1.056 & 0.656 & 0.287 & 0.139 & 0.218 & 0.047 & \begin{tabular}{|l|l}
0.083 \\
\end{tabular} & 0.036 & 0.02 \\
\hline 4 & 0.704 & 0.328 & 0.430 & 0.418 & 0.164 & 0.140 & 0.124 & 0.036 & 0.069 \\
\hline 5 & 0.704 & 0.328 & 0.143 & 0.279 & 0.055 & 0.140 & \begin{tabular}{|l}
0.083 \\
\end{tabular} & 0.072 & 0.046 \\
\hline 6 & 1.056 & 0.164 & 0.143 & 0.558 & 0.109 & 0.140 & 0.165 & 0.036 & 0.069 \\
\hline 7 & 1.056 & 0.164 & 0.574 & 0.558 & 0.218 & 0.186 & 0.165 & 0.108 & 0.092 \\
\hline 8 & 0.352 & 0.492 & 0.287 & 0.558 & 0.109 & 0.093 & \begin{tabular}{|l|l|}
0.041 \\
\end{tabular} & 0.143 & 0.092 \\
\hline 9 & 1.408 & 0.656 & 0.430 & 0.279 & 0.055 & 0.186 & 0.041 & 0.143 & 0.046 \\
\hline 10 & 1.056 & 0.328 & 0.430 & 0.418 & 0.218 & 0.093 & 0.165 & 0.108 & 0.069 \\
\hline & & & & & & & & & \\
\hline 100 & 0.704 & 0.656 & 0.287 & 0.139 & & 0.140 & 0.083 & 0.108 & 0.0 \\
\hline
\end{tabular}

\section{Normalisasi Data}

Himpunan data yang telah di bobotkan dilakukan normalisasi untuk meratakan ukuran jarak dan keragaman data pada atribut yang akan digunakan pada perhitungan clustering sehingga menghindari data yang outlier [2]. Normalisasi data dilakukan dengan Min-Max Normalization. Berikut pada Tabel 
4 merupakan hasil himpunan data yang telah dilakukan normalisasi data.

Tabel 4. Himpunan Data Hasil Normalisasi \begin{tabular}{|l|l|l|l|l|l|l|l|l|l|}
\hline Sekolah & IND 1 & IND 2 & IND 3 & IND 4 & IND 5 & IND 6 & IND 7 & IND 8 & IND 9 \\
\hline
\end{tabular}

\begin{tabular}{|c|c|c|c|c|c|c|c|c|c|}
\hline 1 & 0.238 & 0.339 & 0.294 & 0.185 & 0.141 & 0.051 & 0.073 & 0.061 & 0.050 \\
\hline 2 & 1.000 & 0.339 & 0.294 & 0.386 & 0.062 & 0.118 & 0.103 & 0.087 & 0.050 \\
\hline 3 & 0.746 & 0.457 & 0.191 & 0.084 & 0.141 & 0.017 & 0.043 & 0.009 & 0.000 \\
\hline 4 & 0.492 & 0.220 & 0.294 & 0.285 & 0.102 & 0.084 & 0.073 & 0.009 & 0.033 \\
\hline 5 & 0.492 & 0.220 & 0.087 & 0.185 & 0.023 & 0.084 & 0.043 & 0.035 & 0.017 \\
\hline 6 & 0.746 & 0.102 & 0.087 & 0.386 & 0.062 & 0.084 & 0.103 & 0.009 & 0.033 \\
\hline 7 & 0.746 & 0.102 & 0.398 & 0.386 & 0.141 & 0.118 & 0.103 & 0.061 & 0.050 \\
\hline 8 & 0.238 & 0.339 & 0.191 & 0.386 & 0.062 & 0.051 & 0.013 & 0.087 & 0.050 \\
\hline 9 & 1.000 & 0.457 & 0.294 & 0.185 & 0.023 & 0.118 & 0.013 & 0.087 & 0.017 \\
\hline 10 & 0.746 & 0.220 & 0.294 & 0.285 & 0.141 & 0.051 & 0.103 & 0.061 & 0.033 \\
\hline$\ldots$ & $\ldots$ & $\ldots$ & $\ldots$ & $\ldots$ & $\ldots$ & $\ldots$ & $\ldots$ & $\ldots$ & $\ldots$ \\
\hline 100 & 0.492 & 0.457 & 0.191 & 0.084 & 0.062 & 0.084 & 0.043 & 0.061 & 0.017 \\
\hline
\end{tabular}

\section{Pengklasteran dengan K-Means}

Hasil himpunan data yang telah dinormalisasi selanjutnya menjadi input untuk perhitungan KMeans dengan Software RapidMiner. Indikator 1 sampai indikator 9 pada himpunan data berperan sebagai atribut 1 sampai atribut 9 pada himpunan data. Berikut merupakan tampilan lembar process pada Software RapidMiner.

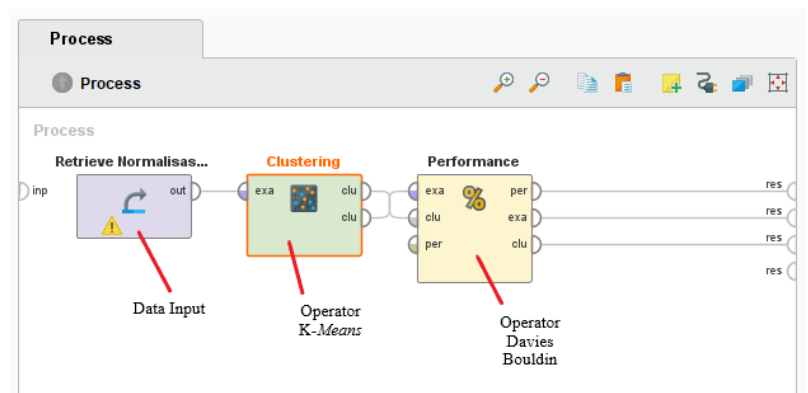

Gambar 3. Tampilan Lembar Proses K-Means

Tabel 5. Hasil K-Means Clustering

\begin{tabular}{|c|c|c|c|}
\hline Sekolah & Cluster & Sekolah & Cluster \\
\hline 1 & cluster_1 & 51 & cluster_1 \\
\hline 2 & cluster_0 & 52 & cluster_1 \\
\hline 3 & cluster_2 & 53 & cluster_0 \\
\hline 4 & cluster_1 & 54 & cluster_0 \\
\hline 5 & cluster_1 & 55 & cluster_1 \\
\hline 6 & cluster_2 & 56 & cluster_2 \\
\hline 7 & cluster_2 & 57 & cluster_0 \\
\hline 8 & cluster_1 & 58 & cluster_1 \\
\hline 9 & cluster_0 & 59 & cluster_0 \\
\hline 10 & cluster_2 & 60 & cluster_0 \\
\hline .. & $\ldots$ & $\ldots$ & $\ldots$ \\
\hline 50 & cluster_1 & 100 & cluster_1 \\
\hline
\end{tabular}

Pada Tabel 5 tersebut merupakan hasil K-Means clustering. Parameter yang digunakan pada Software RapidMiner, yaitu jumlah $\mathrm{k}=3$ karena cluster yang ingin dibentuk berjumlah 3, yaitu Excellent School; Good School; dan Improvement School. Kemudian, digunakan "numerical measures" dan dipilih perhitungan "Euclidean Distance" untuk menghitung jarak antara data dengan pusat cluster. Cluster model yang terbentuk dari hasil K-Means clustering tersebut, yaitu cluster_0 berjumlah 23 items; cluster_1 berjumlah 45 items; dan cluster_2 berjumlah 32 items.

\section{Pengklasteran dengan K-Medoids}

Sama halnya dengan langkah dan parameter pada proses perhitungan K-Means, berikut pada Gambar 4 merupakan tampilan lembar process yang digunakan untuk perhitungan dengan $\mathrm{K}$-Medoids Clustering. Perbedaan hasil clustering dari algoritma K-Means dan K-Medoids dapat terjadi karena perbedaan centroid. Centroid yang dihasilkan pada algoritma K-Means menggunakan nilai rata-rata tiap cluster [8], sedangkan algoritma $\mathrm{K}$-Medoids menggunakan perwakilan objek yang representatif terhadap suatu cluster [9]. Perbedaan nilai data yang sangat kecil dapat menjadi salah satu akibat suatu data berpindah cluster saat menggunakan kedua algoritma yang berbeda tersebut.

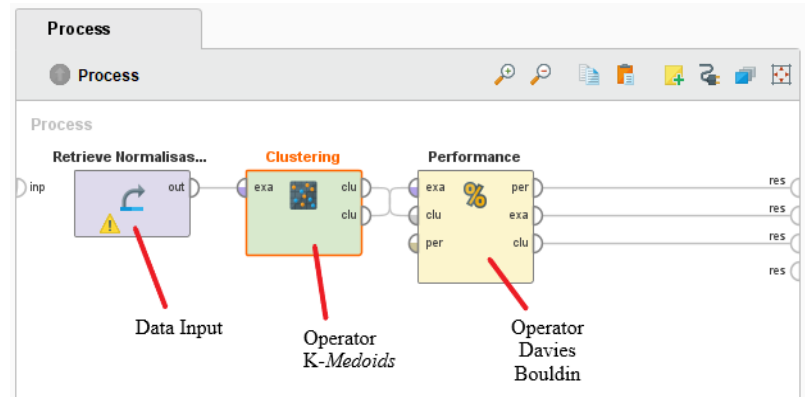

Gambar 4. Tampilan Lembar Proses K-Medoids

Tabel 6. Hasil K-Medoids Clustering

\begin{tabular}{|c|c|c|c|}
\hline Sekolah & Cluster & Sekolah & Cluster \\
\hline 1 & cluster_2 & 51 & cluster_0 \\
\hline 2 & cluster_1 & 52 & cluster_0 \\
\hline 3 & cluster_2 & 53 & cluster_1 \\
\hline 4 & cluster_0 & 54 & cluster_1 \\
\hline 5 & cluster_2 & 55 & cluster_0 \\
\hline 6 & cluster_1 & 56 & cluster_1 \\
\hline 7 & cluster_1 & 57 & cluster_1 \\
\hline 8 & cluster_0 & 58 & cluster_2 \\
\hline 9 & cluster_1 & 59 & cluster_1 \\
\hline 10 & cluster_1 & 60 & cluster_1 \\
\hline$\ldots$ & $\ldots$ & $\ldots$ & $\ldots$ \\
\hline 50 & cluster_2 & 100 & cluster_2 \\
\hline
\end{tabular}

Tabel 6 tersebut merupakan hasil perhitungan KMedoids Clustering dari Software RapidMiner. Cluster model yang terbentuk dari hasil tersebut, yaitu cluster_0 berjumlah 20 items; cluster_1 berjumlah 44 items; dan cluster_2 berjumlah 36 items. Cluster model yang dihasilkan tersebut 
berbeda dengan cluster model pada K-Means clustering, serta hasil centroid yang dihasilkan juga berbeda dengan K-Means clustering.

\section{Perbandingan Hasil Pengklasteran dengan Davies Bouldin Index}

Untuk menentukan hasil clustering yang paling baik antara algoritma K-Means dan K-Medoids digunakan perbandingan nilai Davies Bouldin Index (DBI). Perhitungan nilai DBI juga dilakukan dengan Software RapidMiner dengan menggunakan operator Cluster Distance Performance seperti yang ditunjukkan pada Gambar 3 dan Gambar 4. Berikut merupakan hasil nilai DBI dari masing-masing algoritma.

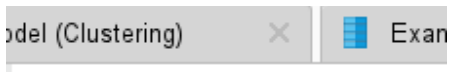

\section{Davies Bouldin}

Davies Bouldin: 0.175

Gambar 5. Hasil DBI dari K-Means

del (Clustering) $\times$ Exarr

\section{Davies Bouldin}

Davies Bouldin: 0.112

Gambar 6. Hasil DBI dari K-Medoids

Gambar 5 dan Gambar 6 tersebut, penentuan cluster yang paling baik dari kedua metode tersebut dilakukan berdasarkan nilai DBI yang paling minimum [10], sehingga dapat dikatakan hasil KMedoids clustering yang terpilih untuk usulan pemetaan sekolah. Nilai DBI yang semakin mendekati nilai nol akan semakin baik hasilnya, dalam artian semakin kecil nilai DBI tersebut semakin dekat kerapatan antar data pada cluster [11].

Selanjutnya, untuk mengetahui label dari tiap cluster yang dihasilkan, maka dilakukan analisis terhadap centroid atau pusat cluster yang dihasilkan dari masing-masing cluster [8], [12]. Berikut merupakan hasil centroid akhir yang dihasilkan pada KMedoids Clustering.
Tabel 7. Hasil Centroid Akhir K-Medoids

\begin{tabular}{|c|c|c|c|}
\hline & Cluster_0 & Cluster_1 & Cluster_2 \\
\hline IND 1 & 0.238 & 1.000 & 0.492 \\
\hline IND 2 & 0.102 & 0.220 & 0.457 \\
\hline IND 3 & 0.398 & 0.191 & 0.191 \\
\hline IND 4 & 0.386 & 0.386 & 0.084 \\
\hline IND 5 & 0.102 & 0.062 & 0.062 \\
\hline IND 6 & 0.051 & 0.051 & 0.084 \\
\hline IND 7 & 0.013 & 0.073 & 0.043 \\
\hline IND 8 & 0.035 & 0.061 & 0.061 \\
\hline IND 9 & 0.033 & 0.050 & 0.017 \\
\hline Rata-rata & 1.357 & 2.094 & 1.491 \\
\hline
\end{tabular}

Berdasarkan Tabel 7 tersebut, rata-rata centroid tertinggi adalah cluster_1 yang diikuti cluster_2 dan cluster_0. Dapat dikatakan sekolah yang memiliki nilai atribut indikator tertinggi akan berkumpul pada centroid cluster yang karakteristiknya sama-sama tinggi. Hasil tersebut dapat menunjukkan hasil centroid yang besar menunjukkan label tertinggi. Oleh karena itu, cluster_1 memiliki label Excellent School; cluster_2 memiliki label Good School; dan cluster_0 memiliki label Improvement School. Berikut pada Tabel 8 merupakan hasi pemetaan sekolah dengan algoritma K-Medoids.

Tabel 8. Hasil Pemetaan Sekolah

\begin{tabular}{|c|c|c|}
\hline Excellent School & Good School & Improvement School \\
\hline Sekolah 2 & Sekolah 1 & Sekolah 4 \\
\hline Sekolah 6 & Sekolah 3 & Sekolah 8 \\
\hline Sekolah 7 & Sekolah 5 & Sekolah 11 \\
\hline Sekolah 9 & Sekolah 13 & Sekolah 16 \\
\hline Sekolah 10 & Sekolah 14 & Sekolah 23 \\
\hline Sekolah 12 & Sekolah 17 & Sekolah 27 \\
\hline Sekolah 15 & Sekolah 18 & Sekolah 34 \\
\hline Sekolah 22 & Sekolah 19 & Sekolah 36 \\
\hline Sekolah 24 & Sekolah 20 & Sekolah 43 \\
\hline Sekolah 25 & Sekolah 21 & Sekolah 44 \\
\hline Sekolah 29 & Sekolah 26 & Sekolah 47 \\
\hline Sekolah 30 & Sekolah 28 & Sekolah 51 \\
\hline Sekolah 31 & Sekolah 32 & Sekolah 52 \\
\hline Sekolah 33 & Sekolah 37 & Sekolah 55 \\
\hline Sekolah 35 & Sekolah 38 & Sekolah 64 \\
\hline Sekolah 39 & Sekolah 42 & Sekolah 67 \\
\hline Sekolah 40 & Sekolah 48 & Sekolah 84 \\
\hline Sekolah 41 & Sekolah 50 & Sekolah 94 \\
\hline Sekolah 45 & Sekolah 58 & Sekolah 96 \\
\hline Sekolah 46 & Sekolah 61 & Sekolah 97 \\
\hline Sekolah 49 & Sekolah 68 & \\
\hline Sekolah 53 & Sekolah 69 & \\
\hline Sekolah 54 & Sekolah 72 & \\
\hline Sekolah 56 & Sekolah 73 & \\
\hline Sekolah 57 & Sekolah 74 & \\
\hline Sekolah 59 & Sekolah 75 & \\
\hline Sekolah 60 & Sekolah 76 & \\
\hline Sekolah 62 & Sekolah 79 & \\
\hline Sekolah 63 & Sekolah 82 & \\
\hline Sekolah 65 & Sekolah 83 & \\
\hline Sekolah 66 & Sekolah 87 & \\
\hline Sekolah 70 & Sekolah 88 & \\
\hline Sekolah 71 & Sekolah 89 & \\
\hline Sekolah 77 & Sekolah 92 & \\
\hline Sekolah 78 & Sekolah 99 & \\
\hline Sekolah 80 & Sekolah 100 & \\
\hline Sekolah 81 & & \\
\hline Sekolah 85 & & \\
\hline Sekolah 86 & & \\
\hline Sekolah 90 & & \\
\hline Sekolah 91 & & \\
\hline Sekolah 93 & & \\
\hline Sekolah 95 & & \\
\hline Sekolah 98 & & \\
\hline
\end{tabular}


Pengklasifikasian dengan Decision Tree C4.5

Hasil clustering yang terpilih, yaitu K-Medoids, dijadikan sebagai data latih atau data training yang di input untuk menghitung algoritma Decision Tree C4.5. Berbeda dengan metode K-Means dan KMedoids yang merupakan unsupervised learning, metode Decision Tree C4.5 merupakan supervised learning. Data yang diinput pada metode Decision Tree C4.5 berupa data yang telah memiliki label, dimana label tersebut merupakan hasil pengolahan machine learning sebelumnya [13], [14]. Pada penelitian ini, cluster_0, cluster_1, dan cluster_2 merupakan label dari data latih hasil clustering. Perhitungan algoritma Decision Tree C4.5 dilakukan dengan menggunakan Software RapidMiner dengan lembar process yang digunakan sebagai berikut.

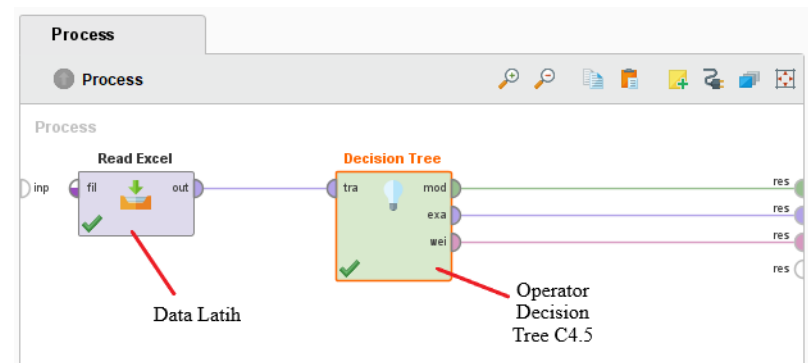

Gambar 7. Tampilan Lembar Proses Decision Tree

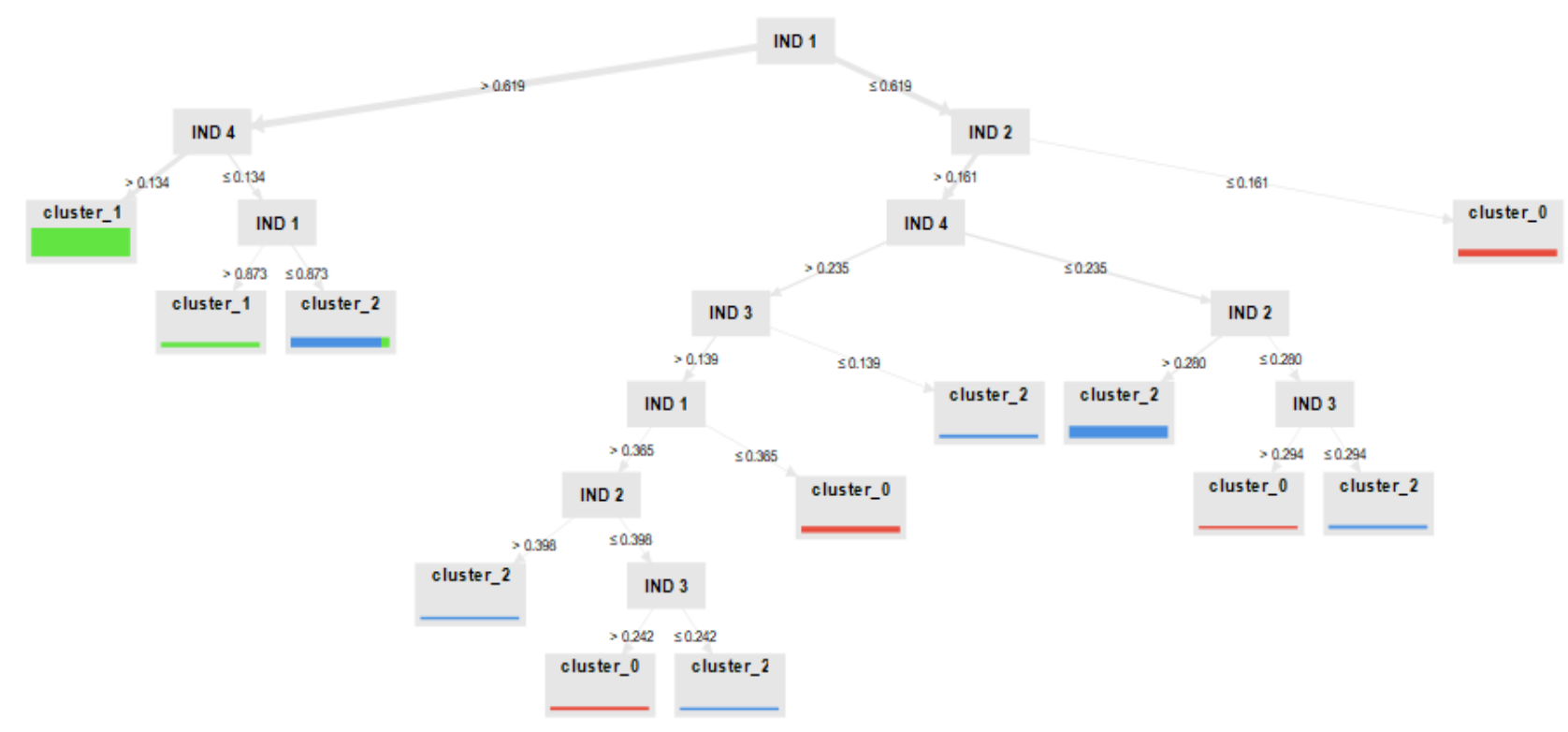

Gambar 8. Hasil Decision Tree C4.5

Gambar 8 tersebut menunjukkan bagan pohon keputusan dari hasil pengolahan decision tree C4.5. Hasil tersebut dapat dijadikan sebagai pola untuk melakukan prediksi klasifikasi suatu sekolah. Pohon keputusan yang dihasilkan hanya menampilkan node untuk IND 1 (indikator 1), IND 2 (indikator 2), IND 3 (indikator 3), dan IND 4 (indikator 4) disebabkan oleh hasil attribute weights keempat indikator tersebut mendominasi atribut lainnya, sehingga hanya dengan menganalisis keempat atribut indikator tersebut telah dapat mengklasifikasi suatu sekolah.

Kemudian, dilakukan pengujian akurasi hasil decision tree tersebut dengan menggunakan Confusion Matrix dengan Software RapidMiner seperti Gambar 9 berikut.

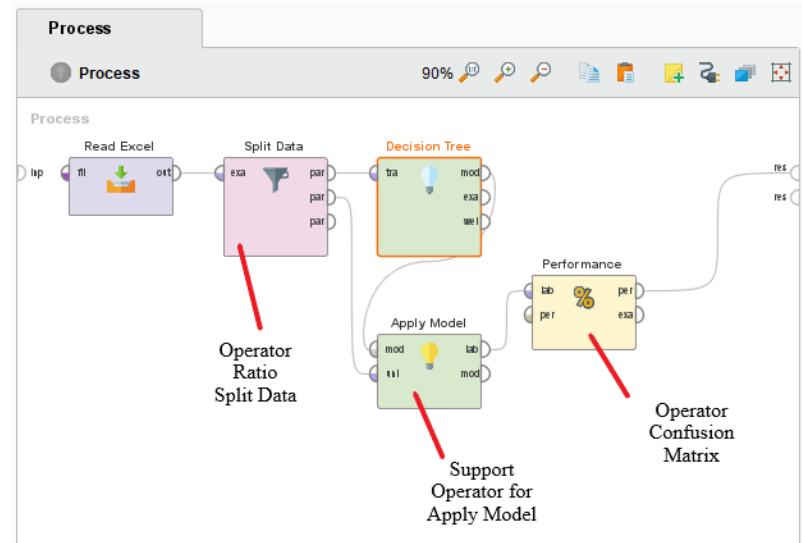

Gambar 9. Tampilan Lembar Proses Confusion Matrix

Untuk perhitungan Confusion Matrix dilakukan split data dengan rasio 50:50, 60:40, 70:30, 80:20, 90:10 antara data training dan data testing dari 100 data yang dimiliki. Berikut Tabel 9 merupakan hasil perhitungan akurasi confusion matrix. 
Tabel 9. Hasil Akurasi Confusion Matrix

\begin{tabular}{|c|c|}
\hline Rasio & Hasil Akurasi \\
\hline $50: 50$ & $84 \%$ \\
\hline $60: 40$ & $85 \%$ \\
\hline $70: 30$ & $90 \%$ \\
\hline $80: 20$ & $95 \%$ \\
\hline $90: 10$ & $90 \%$ \\
\hline
\end{tabular}

Berdasarkan Tabel 9 tersebut, perbandingan hasil akurasi terbesar berada pada rasio 80:20 sedangkan hasil akurasi terkecil berada pada rasio 50:50. Pada rasio 90:10 terdapat penurunan hasil akurasi dikarenakan terdapat data yang belum muncul pada proses pembelajaran sehingga pengklasifikasian tidak dapat dilakukan dengan baik oleh sistem [15]. Sedangkan, dari rasio 50:50 sampai dengan rasio 80:20 hasil akurasi cenderung mengalami peningkatan dikarenakan semakin banyak data training yang muncul pada sistem [15]. Semakin banyak data yang dikenali sistem pada keadaan tersebut memungkin rules data sudah muncul sebelumnya pada proses pembelajaran, sehingga sistem dapat mengklasifikasi dengan baik.

Selanjutnya, dilakukan simulasi dengan menggunakan model decision tree rasio 80:20 untuk data testing baru. Rasio 80:20 digunakan karena pada model tersebut memiliki hasil akurasi confusion matrix paling besar. Simulasi dilakukan guna memprediksi label cluster untuk data sekolah baru dengan menggunakan pola decision tree yang dihasilkan. Data testing yang digunakan dengan asumsi data sekolah ke-101 ditunjukkan sebagai berikut.
Tabel 10. Data Testing Baru

\begin{tabular}{|c|c|c|c|c|c|}
\hline Sekolah & IND 1 & IND 2 & IND 3 & IND 4 & IND 5 \\
\hline 101 & 0.746 & 0.457 & 0.191 & 0.386 & 0.141 \\
\hline \multirow{6}{*}{} & IND 6 & IND 7 & IND 8 & IND 9 & Cluster \\
\cline { 2 - 6 } & 0.118 & 0.103 & 0.061 & 0.017 & $?$ \\
\cline { 2 - 6 }
\end{tabular}

Untuk melakukan simulasi prediksi data testing baru dilakukan dengan Software RapidMiner dengan process yang ditunjukkan pada Gambar 10. Data training yang digunakan merupakan 80 data dari hasil split data pada model rasio 80:20. Sedangkan, data testing yang digunakan merupakan data testing baru untuk data sekolah ke-101.

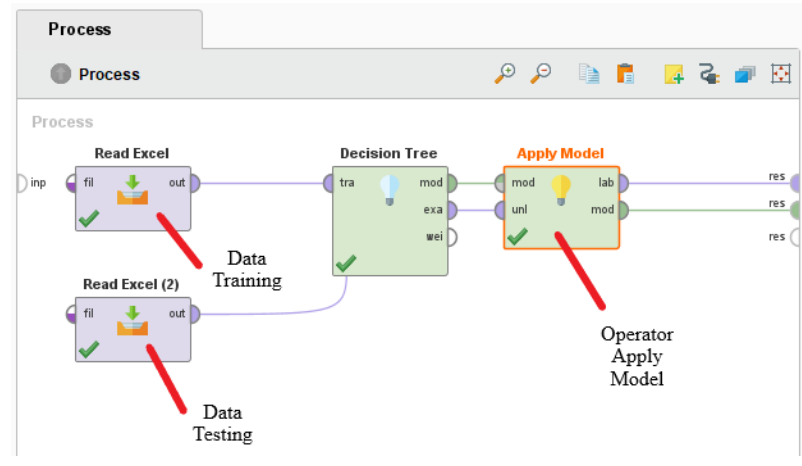

Gambar 10. Tampilan Lembar Proses Simulasi

Dengan menggunakan proses pada Gambar 10, hasil simulasi prediksi ditunjukkan pada Gambar 11 di bawah ini. Hasil prediksi ditunjukkan pada kolom "prediction (Cluster)" yang disertai kolom "confidence(cluster_1)" sebesar 1. Hasil prediksi tersebut menunjukkan bahwa data testing baru untuk asumsi sekolah ke-101 memiliki label cluster_1. Hasil "confidence(cluster_1)" sebesar 1 menunjukkan bahwa data testing baru tersebut masuk ke cluster_1.

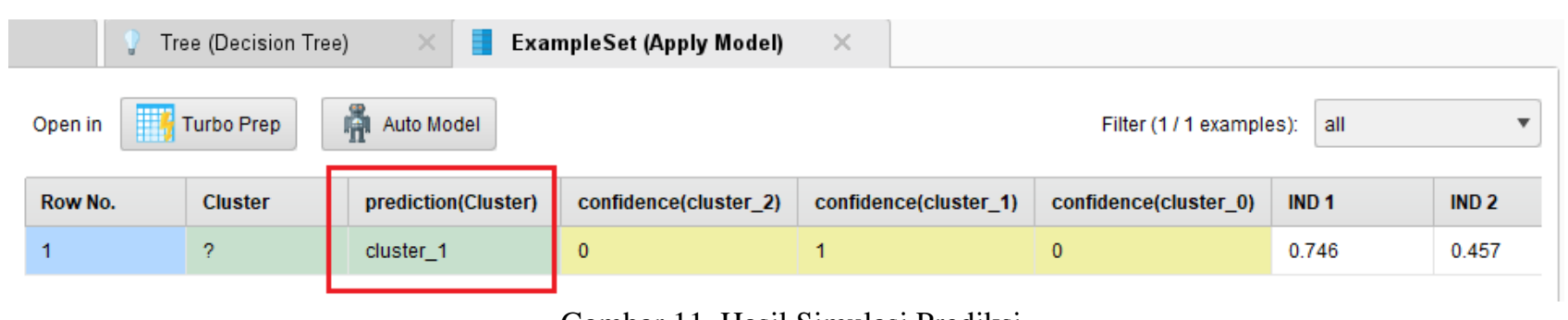

Gambar 11. Hasil Simulasi Prediksi

\section{KESIMPULAN}

Berdasarkan pengumpulan dan pengolahan data yang dilakukan pada penelitian ini, dapat ditarik kesimpulan sebagai berikut:

Instrumen indikator pemetaan sekolah dirancang untuk melakukan penilaian terhadap kualitas masing-masing sekolah yang dimiliki yayasan pendidikan XYZ. Instrumen tersebut merupakan alat penilaian yang terdiri dari indikator dan rubrik yang terdiri dari bagian Sekolah Ideal, Sekolah Sehat, Sekolah Mutu, dan Sekolah Juara.

Hasil reduksi dengan Value Engineering didapatkan indikator prioritas untuk atribut himpunan data, yaitu tingkat pemenuhan daya tampung; tertib LPJ keuangan yang outstanding; persentase murid 
diterima PTN; prestasi akademik lembaga Kemendikbud/resmi; akreditasi sekolah; rata-rata penilaian DP4 guru; prestasi non-akademik lembaga Kemendikbud/resmi; persentase pemenuhan sarana dan prasarana; dan rata-rata penilaian DP4 tenaga kependidikan. Kemudian, dengan menggunakan metode AHP (Analytical Hierarchy Process) didapatkan bobot atribut tersebut berturut-turut, yaitu $0.35190 ; 0.16408 ; 0.14338 ; 0.13942 ; 0.05453$; $0.04654 ; 0.04137 ; 0.03584$; dan 0.02295 .

Hasil simulasi rancangan pemetaan yayasan pendidikan XYZ dengan K-Means Clustering didapatkan pada cluster_0 berjumlah 23 items; cluster_1 berjumlah 45 items; dan cluster_2 berjumlah 32 items. Sedangkan, dengan K-Medoids Clustering didapatkan hasil cluster_0 berjumlah 20 items; cluster_1 berjumlah 44 items; dan cluster_2 berjumlah 36 items.

Hasil perbandingan clustering menggunakan metode Davies Bouldin Index didapatkan nilai DBI dari algoritma K-Means adalah sebesar 0.175. Sedangkan, nilai DBI dari algoritma K-Medoids adalah sebesar 0.112 sehingga hasil K-Medoids yang terpilih untuk usulan pemetaan sekolah.

Pola prediksi pemetaan sekolah dengan metode Decision Tree C4.5 dihasilkan melalui bagan pohon keputusan. Sedangkan, hasil simulasi prediksi dengan menggunakan model rasio 80:20 didapatkan bahwa data testing baru dengan asumsi sekolah ke101 masuk ke cluster_1 dengan tingkat akurasi sebesar $95 \%$.

\section{UCAPAN TERIMA KASIH}

Terima kasih kepada Bapak Budi Aribowo selaku pembimbing pada penelitian ini, terima kasih kepada Yayasan XYZ khususnya Tim Pemetaan Sekolah atas kesediaan menjadi narasumber sekaligus objek penelitian serta terimakasih kepada Lembaga Penelitian dan Pengabdian kepada Masyarakat Universitas Al Azhar Indonesia melalui pendanaan Grant Internal Tahun Anggaran 2021.

\section{REFERENSI}

[1] D. N. L. Laksana, "Pendidikan Berkualitas dan Berkelanjutan di Era Pembelajaran Abad 21," J. Ilm. Pendidik. Citra Bakti, vol. 5, no. 1, pp. 1-5, 2018.

[2] G. S. Nugraha, Hairani, and R. F. P. Ardi, "Aplikasi Pemetaan Kualitas Pendidikan di
Indonesia Menggunakan Metode K-Means,' J. MATRIK, vol. 17, no. 2, pp. 13-23, 2018.

[3] N. Afifah, "Sistem Pendidikan di Indonesia," 2020.

[4] D. M. D. Kamayuda, "Perencanaan Strategi Bersaing Sekolah dalam Meningkatkan Jumlah Peserta Didik Baru di Salah Satu Sekolah Swasta Salatiga," J. Manaj. Pendidik., vol. 3, no. 1, 2016.

[5] L. Novita, "Indikkator Mutu Sekolah Menurut Perspektif Orang Tua Siswa di SMP Negeri 2 Bantul," J. Kebijak. Pendidik., vol. VI, no. 2, pp. 184-193, 2017.

[6] M. F. Pasaribu and R. Puspita, "Tahap Informasi, Kreatif ], dan Analisa Pada Rekayasa Nilai Untuk Meningkatkan Kualitas Pelayanan Hotel," Ind. Eng. J., vol. 5, no. 2, pp. 46-51, 2016.

[7] A. E. Munthafa and H. Mubarok, "Penerapan Metode Analytcal Hierarchy Process dalam Sistem Pendukung Keputusan Penentuan Mahasiswa Berprestasi," J. Siliwangi, vol. 3, no. 2, pp. 192-201, 2017.

[8] A. K. Wardhani, "Implementasi Algoritma K-Means untuk Pengelompokkan Penyakit Pasien pada Puskesmas Kajen Pekalongan," J. Transform., vol. 14, no. 1, pp. 30-37, 2016.

[9] F. Farahdinna, I. Nurdiansyah, A. Suryani, and A. Wibowo, "Perbandingan Algoritma K-means dan K-medoids dalam Klasterisasi Produk Asuransi Perusahaan Nasional," $J$. Ilm. FIFO, vol. XI, no. 2, pp. 208-214, 2019.

[10] A. Badruttamam and D. A. I. Maruddani, "Penerapan Analisis Klaster K -Modes Dengan Validasi Davies Bouldin Index Dalam Menentukan Karakteristik Kanal Youtube Di Indonesia (Studi Kasus: 250 Kanal YouTube Indonesia Teratas Menurut Socialblade )," vol. 9, pp. 263-272, 2020.

[11] A. F. Muhammad, "Klasterisasi Proses Seleksi Pemain Menggunakan Algoritma KMeans," pp. 1-5, 2015.

[12] A. P. Windarto, U. Indriani, M. R. Raharjo, and L. S. Dewi, "Bagian 1: Kombinasi Metode Klastering dan Klasifikasi ( Kasus Pandemi Covid-19 di Indonesia )," vol. 4, pp. 855-862, 2020.

[13] Galih, "Data Mining di Bidang Pendidikan untuk Analisa Prediksi Kinerja Mahasiswa dengan Komparasi 2 Model Klasifikasi pada STMIK Jabar," J. Teknol. Sist. Inf. dan Apl., vol. 2, no. 1, pp. 23-30, 2019.

[14] P. Kasih, "Pemodelan Data Mining Decision Tree Dengan Classification Error Untuk 
Seleksi Calon Anggota Tim Paduan Suara," Innov. Res. Informatics, vol. 1, no. 2, pp. 6369, 2019.

[15] A. A. Mahardhika, R. Saptono, and R. Anggrainingsih, "Sistem Klasifikasi Feedback Pelanggan dan Rekomendasi
Soluasi Atas Keluhan di UPT PUSKOM UNS dengan Algoritma Naive Bayes Classifier dan Consine Similarity," J. ITSMART, vol. 4, no. 1, pp. 36-42, 2015. 